\title{
INHIBITION OF BACTERIAL GROWTH BY CITRATE
}

\author{
KO IMAI, ISAO BANNO AND TEIJI IIJIMA \\ The Institute for Fermentation, Osaka, 4-54, Juso-Nishinocho, \\ Higashiyodogawa-ku, Osaka
}

(Received April 30, 1970)

\begin{abstract}
According to Bergey's Manual of Determinative Bacteriology, 7th edition, the genus Arthrobacter is divided into two groups, one of which utilizes citrate as a sole organic nutrient and the other does not utilize citrate. Among authentic strains of this genus, the growth of Arthrobacter pascens IFO 12139 and Arthrobacter simplex IFO 12069 was inhibited by citrate. It was found that $A$. pascens IFO 12139 required bivalent cation(s) for growth and failed to grow when the medium contained excess of citrate against bivalent cations. On the other hand, A. simplex IFO 12069 could not utilize citrate as a sole source of carbon, and citrate inhibited glucose utilization of the organism. Among many strains belonging to the genera Corynebacterium, Brevibacterium, and Bacillus, growth was inhibited by citrate.
\end{abstract}

Utilization of citrate is one of important keys in the genus Arthrobacter and in the family Enterobacteriaceae. Some investigators stated that many of the so-called "citrate-negative" Enterobacteria in Koser's medium metabolized citrate if the medium was supplied with an energy source and/or growth factors (1-3). The genus Arthrobacter is divided into two groups; one of them utilizes citrate as a sole source of organic nutrient and the other does not. When six authentic strains belonging to the former group of the genus were reexamined for their ability to utilize citrate, it was found that the growth of $A$. pascens IFO 12139 and A. simplex IFO 12069 was inhibited by citrate. The present paper describes the details of this growth inhibition by citrate.

\section{MATERIALS AND METHODS}

Organisms. All the strains used in these experiments have been maintained in this Institute. Six authentic strains of the genus Arthrobacter used in this work were received from American Type Culture Collection (ATCC), Rockville, Md., U.S.A. The ATCC strain number of Arthrobacter is shown in Table 2.

Media. Two kinds of media for the test of citrate utilization were 
Table 1. Constituents of the assay medium for $\mathrm{CO}_{2}$ production from glucose in $A$. pascens IFO 12139.

Tris- $\mathrm{HCl}$ buffer ( $\mathrm{pH} 7.2$ )

Glucose

Glucose $\left[\mathrm{U}^{-14} \mathrm{C}\right](22 \mathrm{mCi}$ 'mmole)

$\mathrm{MgCl}_{2}$

Sodium citrate

Cell suspension

Total volume

$$
\begin{gathered}
100 \mu \text { moles } \\
10 \mu \text { moles } \\
0.1 \mu \mathrm{Ci} \\
0 \text { or } 5 \mu \text { moles } \\
0 \text { or } 1.0 \% \\
0.5 \mathrm{ml} \\
3.0 \mathrm{ml}
\end{gathered}
$$

prepared by Koser's and Christensen's methods. The constituents of the two media were as follow: Koser's medium: Citric acid $2 \mathrm{~g}, \mathrm{NaCl} 5 \mathrm{~g}$, $\mathrm{MgSO}_{4} \cdot 7 \mathrm{H}_{2} \mathrm{O} 0.2 \mathrm{~g}, \mathrm{NH}_{4} \mathrm{H}_{2} \mathrm{PO}_{4} 1 \mathrm{~g}$, distilled water $1,000 \mathrm{ml}$, pH 6.8. Christensen's medium : Sodium citrate $3 \mathrm{~g}$, glucose $0.2 \mathrm{~g}$, yeast extract $0.5 \mathrm{~g}$, ferric ammonium citrate $0.4 \mathrm{~g}, \mathrm{KH}_{2} \mathrm{PO}_{4} 1 \mathrm{~g}, \mathrm{NaCl} 5 \mathrm{~g}$, agar $20 \mathrm{~g}$, distilled water $1,000 \mathrm{ml}$, Phenol Red (0.2\% soln.) $6 \mathrm{ml}, \mathrm{pH} 6.8-6.9$.

Influence of citrate on bacterial growth was examined with a basal medium and nutrient both. The basal medium contained $\left(\mathrm{NH}_{4}\right)_{2} \mathrm{SO}_{4} 2 \mathrm{~g}$, $\mathrm{KH}_{2} \mathrm{PO}_{4} 0.25 \mathrm{~g}, \quad \mathrm{~K}_{2} \mathrm{HPO}_{4} 0.25 \mathrm{~g}, \quad \mathrm{MgSO}_{4} \cdot 7 \mathrm{H}_{2} \mathrm{O} \quad 0.25 \mathrm{~g}, \quad \mathrm{FeSO}_{4} \cdot 7 \mathrm{H}_{2} \mathrm{O} \quad 0.01 \mathrm{~g}$, $\mathrm{MnSO}_{4} \cdot 6 \mathrm{H}_{2} \mathrm{O} 0.01 \mathrm{~g}$, biotin $1 \mu \mathrm{g}$, calcium pantothenate $200 \mu \mathrm{g}$, folic acid $1 \mu \mathrm{g}$, inositol $1,000 \mu \mathrm{g}$, niacin $200 \mu \mathrm{g}, p$-aminobenzoic acid $100 \mu \mathrm{g}$, pyridoxine- $\mathrm{HCl}$ $20 \mathrm{c} \mu \mathrm{g}$, riboflavin $100 \mu \mathrm{g}$, thiamine- $\mathrm{HCl} 200 \mu \mathrm{g}$, choline $500 \mu \mathrm{g}$, distilled water $1,000 \mathrm{ml}, \mathrm{pH} 7.2$. Composition of the nutrient broth was beef extract $3 \mathrm{~g}$, peptone $5 \mathrm{~g}$, yeast extract $3 \mathrm{~g}$, distilled water $1,000 \mathrm{ml}$, $\mathrm{pH} 7.2$. The supplements, such as citrate, glucose, pyruvate, and malate, were autoclaved separately and added to the above media.

Determination of bacterial growth. Young bacterial cells in $5 \mathrm{ml}$ of nutrient broth were collected by centrifugation, washed with sterilized water, and resuspended in $5 \mathrm{ml}$ of sterilized water. An aliquot of the bacterial suspension was inoculated into tubes containing $5 \mathrm{ml}$ of the basal medium supplemented with the test material. These tubes were incubated on a reciprocal shaker at $28^{\circ}$ for 7 days. After incubation, the optical density was measured at $600 \mathrm{~m} \mu$ in $12-\mathrm{mm}$ tube by a Shimadzu Spectronic 20 (Shimadzu Seisakusho Ltd.).

Another examination of $A$. simplex IFO 12069 was made in a series of nutrient broth media by the same method of incubation. Growth was determined by measuring the optical density at $600 \mathrm{~m} \mu$ in $18-\mathrm{mm}$ Pyrex tube every $2 \mathrm{hr}$ with the use of a Coleman Spectrophotometer (Coleman Instruments Corporation).

Preparation of intact cells. Young bacterial cells in $5 \mathrm{ml}$ of nutrient broth culture were inoculated into $500 \mathrm{ml}$ of the basal medium supplemented with $0.3 \%$ glucose and $0.3 \%$ yeast extract, and was incubated on a reciprocal shaker at $28^{\circ}$ for $20 \mathrm{hr}$. Cells were harvested by centrifugation, washed 
Table 2. Citrate utilization by the genus Arthrobacter.

\begin{tabular}{|c|c|c|c|}
\hline Species & $\begin{array}{l}\text { Strain No. } \\
\text { IF O (ATCC) }\end{array}$ & $\begin{array}{l}\text { Koser's } \\
\text { medium } \\
\text { a) }\end{array}$ & $\begin{array}{l}\text { Christensen's } \\
\text { medium } \\
\text { b) }\end{array}$ \\
\hline Arthrobacter globiformis & $12137 \quad(8010)$ & + & + \\
\hline Arthrobacter pascens & $12139(13346)$ & - & + \\
\hline Arthrobacter simplex & $12069 \quad(6946)$ & - & - \\
\hline Arthrobacter oxydans & $12138(14358)$ & + & + \\
\hline Arthrobacter aurescens & $12136(13344)$ & + & + \\
\hline Arthrobacter ureafaciens & $12140 \quad(7562)$ & + & + \\
\hline
\end{tabular}

a) Citrate utilization was judged by whether the organisms could grow in the medium.

b) Citrate utilization was judged by color change of the $\mathrm{pH}$ indicator.

twice with distilled water, and resuspended in $25 \mathrm{ml}$ of $0.1 \mathrm{M}$ Tris- $\mathrm{HCl}$ buffer ( $\mathrm{pH}$ 7.0). The intact cell suspension was used in the following experiment.

Radioisotope experiment. An assay medium (Table 1) was poured into Warburg flasks sealed with a rubber cap and was incubated at $28^{\circ}$. After 30 -min incubation, $0.5 \mathrm{ml}$ of $1 \mathrm{~N} \mathrm{H}_{2} \mathrm{SO}_{4}$ was injected into the medium with a syringe through the rubber cap and $0.3 \mathrm{ml}$ of hyamine-ethanol solution was then injected with a syringe into the center well of each Warburg flask. The Warburg flasks were further incubated at $28^{\circ}$ for $20 \mathrm{~min}$. Radioactivity of $0.2 \mathrm{ml}$ of each hyamine-ethanol solution absorbed $\mathrm{CO}_{2}$ was counted in a vial containing $10 \mathrm{ml}$ of scintillation fluid (DPO $150 \mathrm{mg}$, POPOP 6,000 mg, toluene $1,000 \mathrm{ml}$ ), by a Packard Tri-Carb Liquid Scintillation Counter.

Assay method for glucose in media. Content of glucose was determined by Glucostat (Worthington Biochemical Corporation).

\section{RESULTS AND DISCUSSION}

The ability of six authentic strains of Arthrobacter to utilize citrate in Koser's and Christensen's media is shown in Table 2. Among the strain tested, A. pascens IFO 12139 could not grow in Koser's medium and $A$. simplex IFO 12069 did not utilize citrate in both media. However, in a medium without vitamins such as Koser's medium, a bacterial strain may not grow if the strain has a nutritional requirement. For this reason, the basal medium containing vitamins was used for further experiments stated below.

Citrate assimilation by $A$. pascens IFO 12139 and A. simplex IFO 12069 was tested in the basal medium supplemented with either glucose, pyruvate, or malate, and combined with various concentrations of sodium citrate. As shown in Fig. 1, A. pascens IFO 12139 could utilize citrate as a sole carbon source when the concentration of citrate was $0.1 \%$ or less, but the organism 


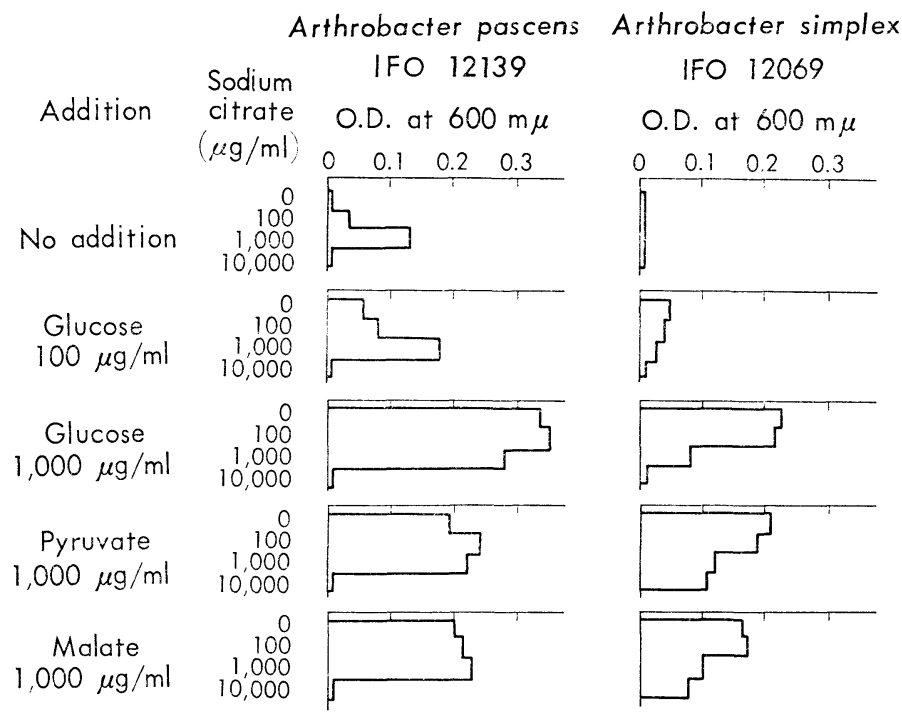

Fig. 1. Growth inhibition by citrate.

Growth in the basal medium supplemented with glucose, pyruvate, or malate, and with various concentrations of sodium citrate was determined by measuring the optical density at $600 \mathrm{~m} \mu$ after 7 days' incubation

could not grow when sodium citrate concentration was $1 \%$, even if the medium was supplemented with glucose, pyruvate, or malate. On the other hand, A. simplex IFO 12069 could not utilize citrate as a sole source of carbon and, when one of available carbon sources was added in the basal medium, the growth decreased in proportion to the concentration of sodium citrate for all kinds of supplemented carbon sources.

The above phenomena were observed not only for sodium salt but also for potassium and ammonium salts of citric acid.

\section{Growth inhibition of A. pascens IFO 12139 by cilrate}

It is noteworthy that the assimilation of citrate in A. pascens IFO 12139 is influenced by concentration of the compound in the medium. Citric acid has a chelating effect against metals. It was anticipated that the phenomenon was caused by chelating of citrate with metals in the medium. A. pascens IFO 12139 was incubated in a series of media containing various concentrations of sodium citrate and of bivalent cations (Table 3). The results are shown in Fig. 2. As A. pascens IFO 12139 could not grow in the medium without bivalent cations $(\mathrm{O})$, it was evident that the organism required one or more of these cations for growth. When the bivalent cations were added to the medium at the ordinary concentration (S), growth of the organism was inhibited by 0.5 to $1 \%$ of sodium citrate but, when the concentration of 
Table 3. Constituents of the medium for testing the effect of bivalent cations on growth inhibition of $A$. pascens IF 12139 by citrate.

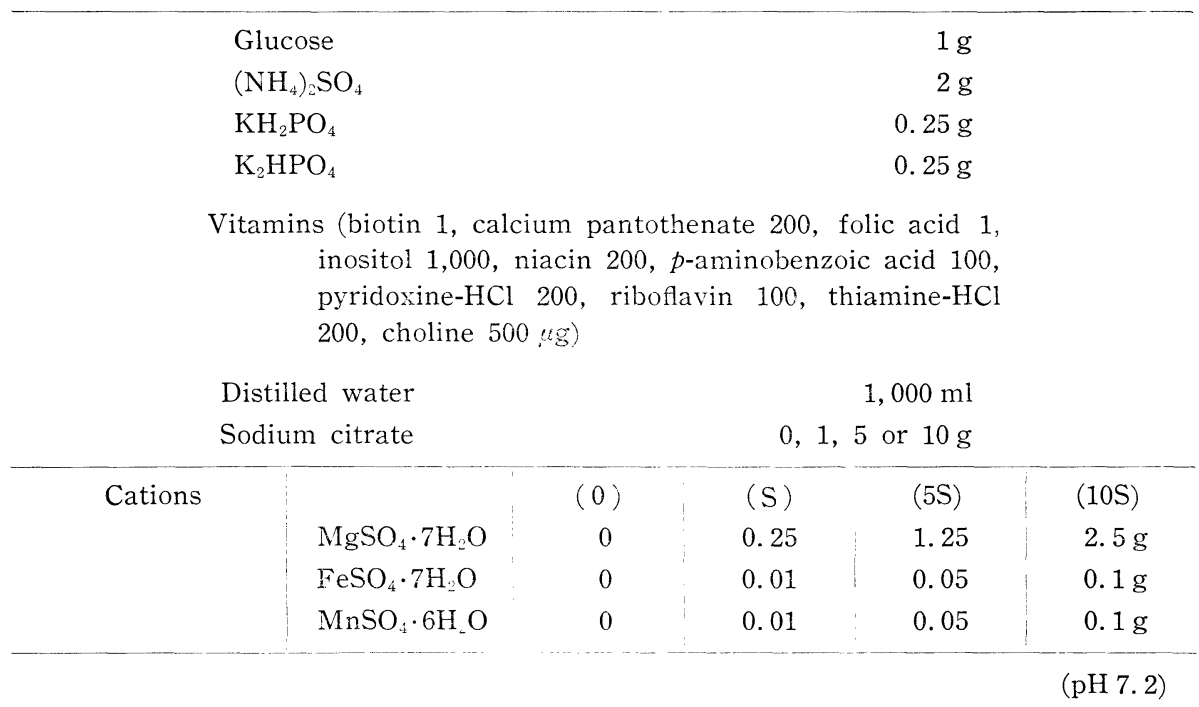

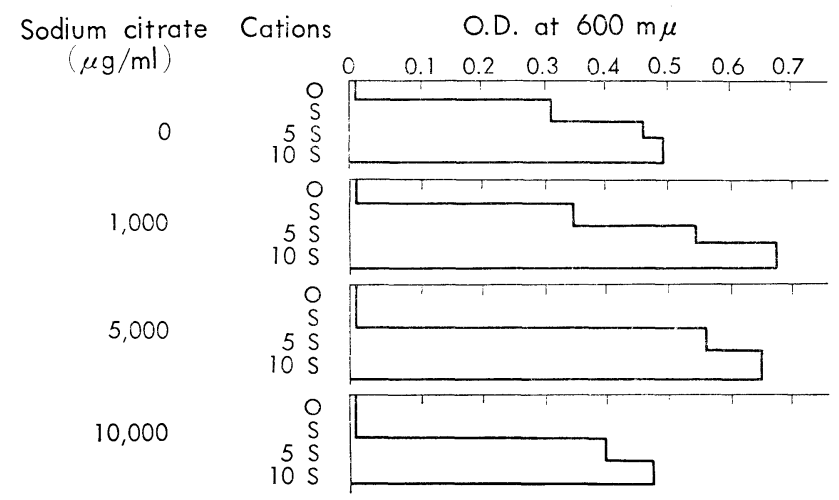

Fig. 2. Effect of bivalent cations on growth inhibition of $A$. pascens IFO 12139 by citrate.

Growth in the medium shown in Table 3 was determined by measuring optical density at $600 \mathrm{~m} \mu$ after 7 days' incubation.

the cations was 5 - or 10 -fold of the ordinary concentration ( $5 \mathrm{~S}$ or $10 \mathrm{~S}$ ), the organism could grow even in the medium containing $1 \%$ of sodium citrate.

In addition, influence of citrate on glucose metabolism in intact cells of A. pascens IFO 12139 was examined. As shown in Fig. 3, citrate did not have any influence on $\mathrm{CO}_{2}$ production from glucose even in the assay medium containing $1 \%$ of sodium citrate. 


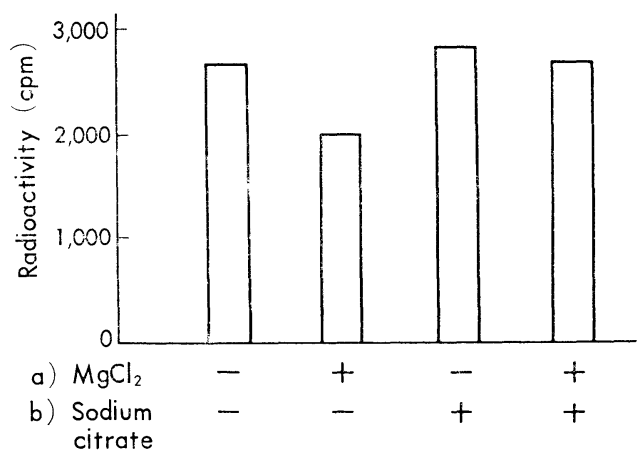

Fig. 3. Influence of citrate on $\mathrm{CO}_{2}$ production from glucose by $A$. pascens IFO 12139.

$\mathrm{CO}_{2}$ production from glucose by intact cells of $A$. pascens IFO 12139 was carried out in the assay medium (Table 1 ).

a) + Assay medium with $5 \mu$ moles $\mathrm{MgCl}_{2}$.

- Assay medium without $\mathrm{MgCl}_{2}$.

b) + Assay medium with $1 \%$ sodium citrate.

- Assay medium without citrate.

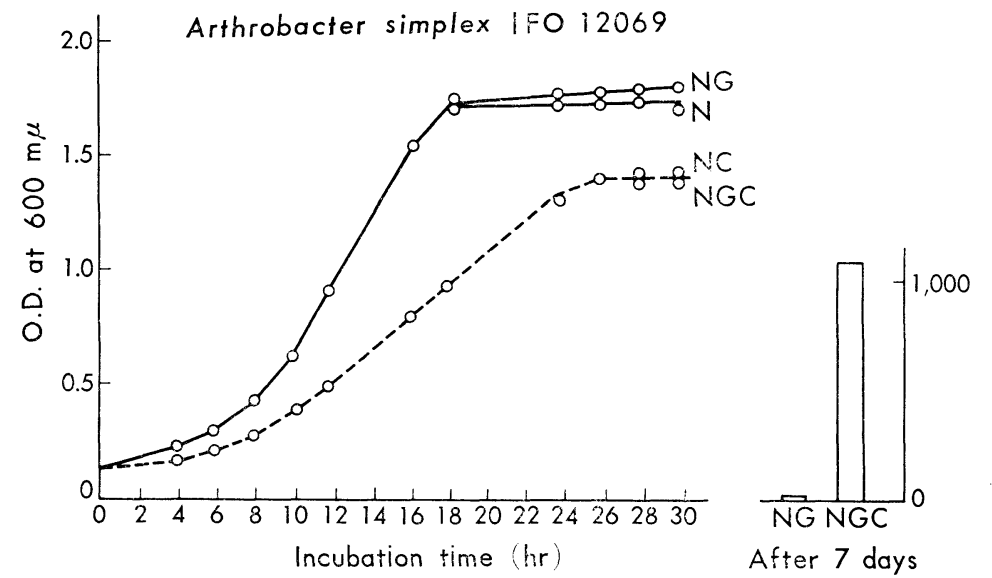

Fig. 4. Inhibition of glucose utilization of $A$. simplex IFO 12069 by citrate.

$N$ : Nutrient broth.

NG: Nutrient broth $+0.1 \%$ glucose.

NC: Nutrient broth $+1 \%$ sodium citrate.

NGC: Nutrient broth $+0.1 \%$ glucose $+1 \%$ sodium citrate. 
Table 4. Utilization of carbon sources by A. simplex IFO 12069 and growth inhibition by citrate in the medium containing available carbon sources.

\begin{tabular}{c|c|c}
\hline Carbon source & Utilization & $\begin{array}{c}\text { Growth in the medium } \\
\text { containing 1\% citrate }\end{array}$ \\
\hline Glucose & a) & - \\
Galactose & + & - \\
Mannose & + & \\
Fructose & - & \\
Xylose & - & + \\
Ribose & - & + \\
Gluconate & - & + \\
Glycerol & - & + \\
Pyruvate & - & + \\
Malate & + & + \\
Fumarate & + & + \\
Glutamate & + & \\
\hline
\end{tabular}

a) + utilization, - no utilization.

b) + growth, - no growth.

Table 5. Citrate utilization of bacteria.

\begin{tabular}{|c|c|c|c|c|c|}
\hline \multirow{2}{*}{ Species } & \multirow{2}{*}{\multicolumn{2}{|c|}{ Strain No. }} & \multicolumn{2}{|c|}{ Koser's medium } & \multirow{2}{*}{$\begin{array}{c}\text { Christensen's } \\
\text { medium }\end{array}$} \\
\hline & & & $0.2 \%$ & $\begin{array}{l}0.07 \% \\
\text { a) }\end{array}$ & \\
\hline $\begin{array}{l}\text { Corynebacterium } \\
\quad \text { flaccumfasciens }\end{array}$ & IFO & 12156 & - & + & + \\
\hline michiganense & 11 & 12158 & - & + & + \\
\hline aquaticum & "I & 12154 & - & + & + \\
\hline rathayi & 11 & 12162 & - & - & - \\
\hline tritici & "l & 12164 & - & + & + \\
\hline Brevibacterium divaricatum & 11 & 12132 & - & + & + \\
\hline vitarumen & "1 & 12143 & - & - & - \\
\hline incertum & "1 & 12145 & - & - & - \\
\hline fuscum & 11 & 12127 & - & + & $\div$ \\
\hline Bacillus mxcerans & 11 & 3490 & - & + & - \\
\hline " pumilus & "I & 12111 & - & + & + \\
\hline " firmus & 11 & 3330 & - & - & - \\
\hline "brevis & $\prime \prime$ & 12334 & - & - & - \\
\hline
\end{tabular}

a) Citric acid concentration was reduced to $0.07 \%$. 
From these results, it seems that growth inhibition of $A$. pascens IFO 12139 by citrate is due to deficiency of bivalent cations from their chelation with citrate.

\section{Growth inhibition of A. simplex IFO 12069 by citrate}

When $1 \%$ of sodium citrate was added, A. simplex IFO 12069 failed to grow in the basal medium containing glucose as carbon source, but did grow in the basal medium containing pyruvate or malate (Fig. 1). It was expected that glucose utilization of the organism was inhibited by citrate. Growth was tested in four kinds of nutrient broth supplemented with glucose and citrate (Fig. 4). When the culture medium contained $1 \%$ of sodium citrate, growth of the organism was repressed and glucose content in the medium (NGC) did not diminish even after 7 days' incubation (Fig. 4). It is evident that glucose utilization of A. simplex IFO 12069 is inhibited by citrate.

A. simplex IFO 12069 utilized glucose, galactose, pyruvate, malate, and glutamate, but did not utilize mannose, fructose, xylose, ribose, gluconate, or glycerol as a sole source of carbon (Table 4). An examination was made to see whether the organism could grow in the basal medium containing $1 \%$ of sodium citrate and one of these available carbon sources. Growth of $A$. simplex IFO 12069 was inhibited by citrate when the source of energy was glucose or galactose, but was not arrested when pyruvate, malate, glutamate, or fumarate was added (Table 4). It is evident that galactose utilization of the organism is also inhibited by citrate. This result will be published in more detail elsewhere.

\section{Growth inhibition of gram-positive bacteria by citrate}

It is an interesting fact that citrate, a member of the TCA cycle, inhibits growth of bacteria. Nobody has discussed the influence of this phenomenon on bacterial taxonomy. It is necessary to investigate the distribution of such inhibition reaction of citrate in bacteria and the examination was carried out on 23 strains of Corynebacterium, 33 strains of Brevibacterium, and 16 strains of Bacillus by the use of the basal medium containing $0.1 \%$ of glucose and $1 \%$ of sodium citrate. The growth of 13 strains shown in Table 5 was inhibited by citrate.

Citrate utilization of the above 13 strains was tested in Christensen's medium and Koser's medium supplemented with vitamins and amino acids. All the 13 strains, including the 8 strains which utilized citrate in Christensen's medium, could not grow in Koser's medium. When the citric acid concentration in Koser's medium was changed from $0.2 \%$ to $0.07 \%$, these 8 strains, which utilized citrate in Christensen's medium, grew in that medium.

When utilization of citrate as a sole source of carbon is examined, bacteria which were judged as positive for citrate utilization in Christensen's medium have to be retested in the newly modified Koser's medium in which 
citric acid concentration was reduced to $0.07 \%$, and vitamins and amino acids were supplemented.

The authors are grateful to Dr. T. Hasegawa, Director of this Institute, and to Dr. R. Kodama, Research Section Chief of this Institute, for their valuable suggestions and discussions in this work.

\section{REFERENCES}

1) R.H. Vaughn, J.T. Osborne, G.T. Wedding, J. Tabachnick, C.G. Beisel and T. Braxton, J. Bacieriol., 60, 119 (1950).

2) I. Lominski, N.S. Conway, E.M. Harper and J.B. Rennie, Nature, 160, 573 (1947).

3) D. Piechand and S. Szturum-Rubinsten, Anin. Inst. Pasteur, 105, 460 (1963). 